\title{
Environment and Obesity in the National Children's Study *
}

\author{
Ambiente e obesidade no National Children's Study
}

\author{
Leonardo Trasande ${ }^{1,2}$ \\ ChrisCronk $^{3}$ \\ Maureen Durkin ${ }^{4}$ \\ MarianneWeiss ${ }^{5}$ \\ DaleSchoeller ${ }^{6}$ \\ Elizabeth Gall ${ }^{4}$ \\ Jeanne $\mathrm{H}_{\text {ewitt }}{ }^{7}$ \\ Aaron Carrel ${ }^{8}$ \\ Philip Landrigan ${ }^{1,2}$ \\ Matthew Gillman ${ }^{9}$
}

\footnotetext{
* This article was originally published by Environ Health Perspect 117:159-166 (2009). doi:10.1289/ ehp.11839 availablevia http:/ /dx.doi.org/[Online12 September 2008] and ispart of thescientific collaboration between Cien Saude Colet and EH P. The authors declarethey haveno competing financial interests. ${ }^{1}$ Department of Community and PreventiveM edicine, M ount Sinai School of M edicine, OneGustaveL. Levy Place, Box 1043, N ew York, NY 10029 USA. leo.trasande@mssm.edu ${ }^{2}$ Department of Pediatrics, M ount Sinai School of Medicine.

${ }^{3} \mathrm{M}$ edical College of Wisconsin.

${ }^{4}$ Department of Population Health Sciences, University of Wisconsin.

${ }^{5}$ College of Nursing, $M$ arquetteUniversity. ${ }^{6}$ Interdepartmental Program in Nutritional Sciences, University of Wisconsin. ${ }^{7} \mathrm{M}$ arineand Freshwater Biomedical Sciences Center, University of WisconsinMilwaukee

${ }^{8}$ Department of Pediatrics, University of Wisconsin.

${ }^{9}$ Department of Ambulatory Careand Prevention, H arvard M edical School.
}

Abstract We describe the approach taken by the National Children's Study (NCS) to understanding the role of environmental factors in the development of obesity. We review the literature with regard to the two core hypotheses in the N CS that relate to environmental origins of obesity and describe strategies that will be used to test each hypothesis. Although it is clear that obesity in an individual results from an imbalance between energy intake and expenditure, control of the obesity epidemic will require understanding of factors in the modern built environment and chemical exposures that may have the capacity to disrupt the link between energy intake and expenditure. Through its embrace of the life-course approach to epidemiology, the N CS will beableto study the origins of obesity from preconception through late adolescence, including factors ranging from genetic inheritance to individual behaviors to the social, built, and natural environ-ment and chemical exposures. It will havesufficient statistical power to examine interactions among these multi ple influences, including gene-environment and geneobesity interactions. A major sec-ondary benefit will derive from the banking of specimens for future analysis.

Key words Bisphenol A, Built environment, Endocrine disruptors, Diet, 0 besity, Physical activity
Resumo Descrevemosa abordagem do National Children's Study (NCS) para entender o papel dos fatores ambientais no desenvolvimento da obesidade. Revisamos a literatura a respeito de duas hipóteses principais no N CS que se relacionam a origens ambientais da obesidade e descrevem estratégias que serão utilizadas para testar cada hipótese. A pesar de estar claro que a obesidadeem um indivíduo éresultado de um desequilíbrio entre consumo e gasto de energia, o controleda epidemia deobesidade requer o entendimento de fatores no ambiente moderno e exposições químicas que podem ter a capacidade de interromper a li gação entre o consumo egasto de energia. Através da aceitação da abordagem do curso de vida a epidemiologia, o NCS será capaz de estudar as origens da obesidade da preconcepção ao final da adolescência, incluindo fatores que vão da herança genética a comportamentos individuais, passando pelo ambiente social, construído e natural e exposições químicas. 0 estudo terá poder estatístico suficiente para examinar as interações entre essas influências múltiplas, incluindo interações entre gene-ambiente e gene-obesidade. U m benefício secundário importante será derivado do banco de espécime para análise futura.

Palavras-chave Bisphenol A, Ambienteconstruído, Disruptores endócrinos, Dieta, O besidade, Atividade física 
Obesity is the consequence of a chronic net positiveenergy bal ance. Theprevalence of obe-sity in American children has trebled in the past 30 years ${ }^{1-3}$. In 2003-2006, 31.9\% of 2- to 19-yearolds had a body mass index (BMI) $\geq 85$ th percentile for age and sex ${ }^{4}$. This great increase in obesity portends future increases in incidence of heart disease ${ }^{5}$, diabetes ${ }^{6}$, stroke, and possibly can$\mathrm{cer}^{7}$ and is thereforeprojected to producethefirst declinein U.S. life expectancy since the Great Depression ${ }^{8}$. The recent explosiveincrease in prevalence of obesity reflects a complex interplay among a) changes in individual behaviors; b) changes in community structure, lifestyle, and the built environment; and c) pos-sibly exposures to certain synthetic chemicals, such as endocrine disruptors (EDs), that may have the capacity to disrupt energy balance.

Control of the obesity epidemic will require understanding each of these factors and the interplay among them. This under-standing will guide development of multipronged evidencebased strategies for obesity control. The goal of this review is to describe the approaches that the National Children's Study (NCS) will employ to develop under-standing of the causes of obesity, especially with regard to environmental factors.

\section{Background}

Behavioral change is critical to the prevention and treatment of childhood obesity. Yet interventions against obesity that focus solely on modifying individual behavior to increase energy expenditure and/or reduce caloric intake in individual children have had limited success in sustaining weight loss or prevent-ing obesity 9 . A successful approach to reducing obesity and its comorbidities must also embrace understanding of community-level factors including the social, built, and natural environments. These environmental influences interact with a child's diet, physical activity, genetic makeup, and metabolism ${ }^{10-12}$. An example of a multipronged approach that took careful cognizance of environmental influences is the success of the state of Arkansas in reducing obesity prevalenceamong school-age children. A thoughtful redesign of the school environment, with changes to school dietary options, imple mentation of universal physical education programs, and reduction of access to sugary soft drinks resulted in a decline in the prevalence of overweight children from $20.8 \%$ in the 2004-2005 school year to $20.4 \%$ in $2005-2006^{13}$.
Access to safe play spaces may also influence activity patterns and thus reduce risk of obesity ${ }^{14,15}$. Direct marketing to children (for example, through television ads during child-focused programming) encourages consumption of high-fat and high-sugar content foods and is a negative environmental influence $\mathrm{e}^{16,17}$.

Unique windows of vulnerability have been identified for many of the environmental exposures linked to obesity ${ }^{12}$. Fetal stressors such as maternal nutritional deprivation and smoking can result in intrauterine growth restriction (IU GR) and thereby influencehypothalamic-pituitary axis programming to increase future risk of obesity and diabetes ${ }^{10}$. Infants born to women with insulin-dependent diabetes are at higher risk of obesity, and milder, diet-con-trolled gestational diabetes may also increase risk ${ }^{18,19}$. M aternal smoking during pregnancy is an independent risk factor for the development of childhood obesity ${ }^{20,21}$. Excess gestational weight gain has been associated with increased child adiposity at 3 years of age in at least one prospective cohort ${ }^{22}$. Exposureto endocrine-disrupting chemicals during pregnancy may enhance the risk for obesity in childhood ${ }^{23}$. Rapid weight gain during the first year of life ${ }^{24}$ and fewer hours of sleep during infancy ${ }^{25}$ further enhance the risk for the development of childhood obesity.

Although previous cohort studies have contributed greatly to identifying many individuallevel factors that contribute to the development of obesity in children and its persistenceinto adulthood both in theU nited States and in other countries $^{11,26-38}$, findings from those previous longitudinal studies have several limitations:

- Previous studies have not fully capitalized on thelife-courseapproach to chronic disease epidemiology ${ }^{39}$, an approach that embraces the concept that adult disease can haveits origins in early life (or even fetal) exposures. Barker and Osmond ${ }^{40}$ promulgated this concept to account for an association between low birth weight and adult ischemic heart disease in Britain and Wales. The concept has been adopted increasingly in the epidemiologic approach to understanding chronic conditions ${ }^{41}$ including obesity ${ }^{42-44}$ and neurodegenerativeconditions ${ }^{45}$. Theapplication of thelifecourse approach to identifying temporal relationships among risk factors for childhood obesity and their interaction is depicted in Figure 1. Multiple studies have documented unique windows of vulnerability to environ-mental hazards that may contribute to the causation of chronic conditions such as obe-sity 21,46 , yet few studies to date 
have collected the scope of data depicted in this figure at multiple points in the life span.

. Although the Centers for Children's Environmental Health and Disease Prevention have collected data on environmental exposures to pregnant women and young children, these research centers haverarely focused on child weight status as an outcome ${ }^{47}$. This weakness is especially relevant in light of new knowledge from animal studies, which suggest that endocrine-disrupting chem-icals may modulate response to dietary intake $e^{48,49}$, disrupt the hypothalamic-pituitary $a \mathrm{xi}^{50}$, and possibly increaserisk for childhood obesity ${ }^{23}$.

- Although some studies have collected ge netic data on participants and have been able to identify polymorphisms that increase risk for obesity, they have not simultaneously collected the data on environmental exposures that are necessary to examine carefully theinteractions of genetic and environmental factors with diet and physical activity.
- Recent studies also suggest that obesity develops as a chronic condition much earlier than the school-age years ${ }^{51}$. Earlier cohort studies that werefirst initiated when obesity in the preschool years was relatively infrequent are unlikely to provide data on exposures in early life that areessential to identify prenatal and early childhood risk factors for obesity.

- M any previous cohorts were limited in their capacity to identify risk factors for obesity that may be unique among $\mathrm{H}$ ispanics, a population for which obesity prevalence is increasing especially rapidly 2,52 .

- Previous cohorts are limited in that they havenot included sufficient numbers of children to draw contrasts between risk factors specific to rural and urban environments ${ }^{34}$.

- Past studies have been unableto allow accurate assessment of the role of access to parks and other places that encourage physical activity among children living in urban areas ${ }^{53}$.

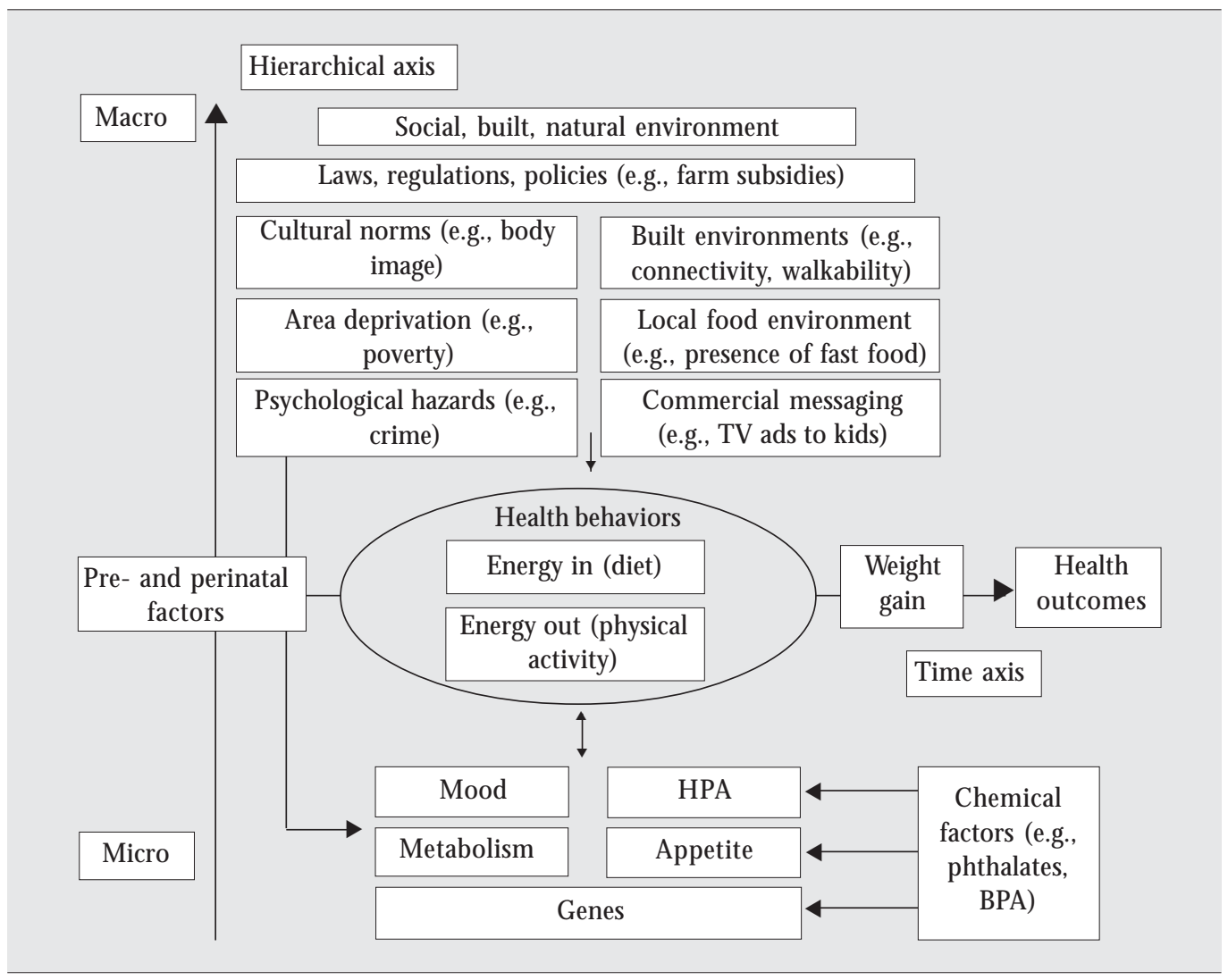

Figure 1. A life-course approach to childhood obesity. Abbreviations: BPA, bisphenol A; H PA, hypothalamic-pituitary axis. The life span is depicted horizontally, while factors are depicted at various levels hierarchi-cally, from the individual-level factors in the lower part of the figure to the community-level factors in the upper part. Adapted from Glass and M cAtee ${ }^{54}$. 
- M any cohort studies were begun before the tripling of childhood obesity prevalence occurred ${ }^{3,55,56}$ - a trend increasingly attributed to the collective effect of community-level factors for which policy changes may be the only effective means for preventing further increases in obesity prevalence ${ }^{9}$. To assess the impact of these more recent community-level factors, new cohorts in which these risk factors exist are needed.

- Although studiesfrom other countries, such as the Avon Longitudinal Study of Parents and Children ${ }^{11,12}$ and the Danish National Birth Cohort ${ }^{57}$, will provide important insights into the etiology of childhood obe-sity, the environmental factors that contribute to obesity in American children are likely to be different, and the pool of genetic poly-morphisms that modify risk may be much different from that of European children.

\section{Progress of the NCS}

In response to increases in the prevalence of obe sity and a number of other chronic con-ditions, the U.S. Congress, through the Children's Health Act of 2000, authorized the $\mathrm{N}$ ational Institute of Child $\mathrm{H}$ ealth and Human Development (NICHD) "to conduct a national longitudinal study of environmental influences (including physical, chemi- cal, biological, and psychosocial) on children's health and development" 58 . The design of the NCS has been extensively described el sewhere ${ }^{59-62}$. With assistance from the staff of the $\mathrm{N}$ ational Center for Health Statistics at the Centers for Disease Control and Prevention, NCS staff developed a multistage clustered sampling approach to enroll a sample of 100,000 live births representative of all American children ${ }^{63}$. Families who areenrolled in the study will participate in a minimum of 13 data collection encounters: at least one visit before conception; two times during pregnancy; at birth; at 6,12 , and 18 months of age in early childhood; at 3, 5, 7, 9, and 12 years of age in childhood; and at 16 and 20 years of age in adolescence (Figure 2). Figure 2 depicts the timeline of visits across the complete study, and Tables 1 and 2 describe the measurements planned for preconception through 3 years of age for the seven Vanguard (pilot) locations. Enrollment of women will occur in 105 primary sampling units (countiesor, in the case of more sparsely populated areas, clusters of counties) and began in January 2009.

The mission of the NCS is to provide the federal government with a scientifically robust guide to disease prevention, and to assure scientific rigor the study has always been hypothesis-driven. Thetopical working groups convened by the NCS Advisory Committee developed initial core hy-

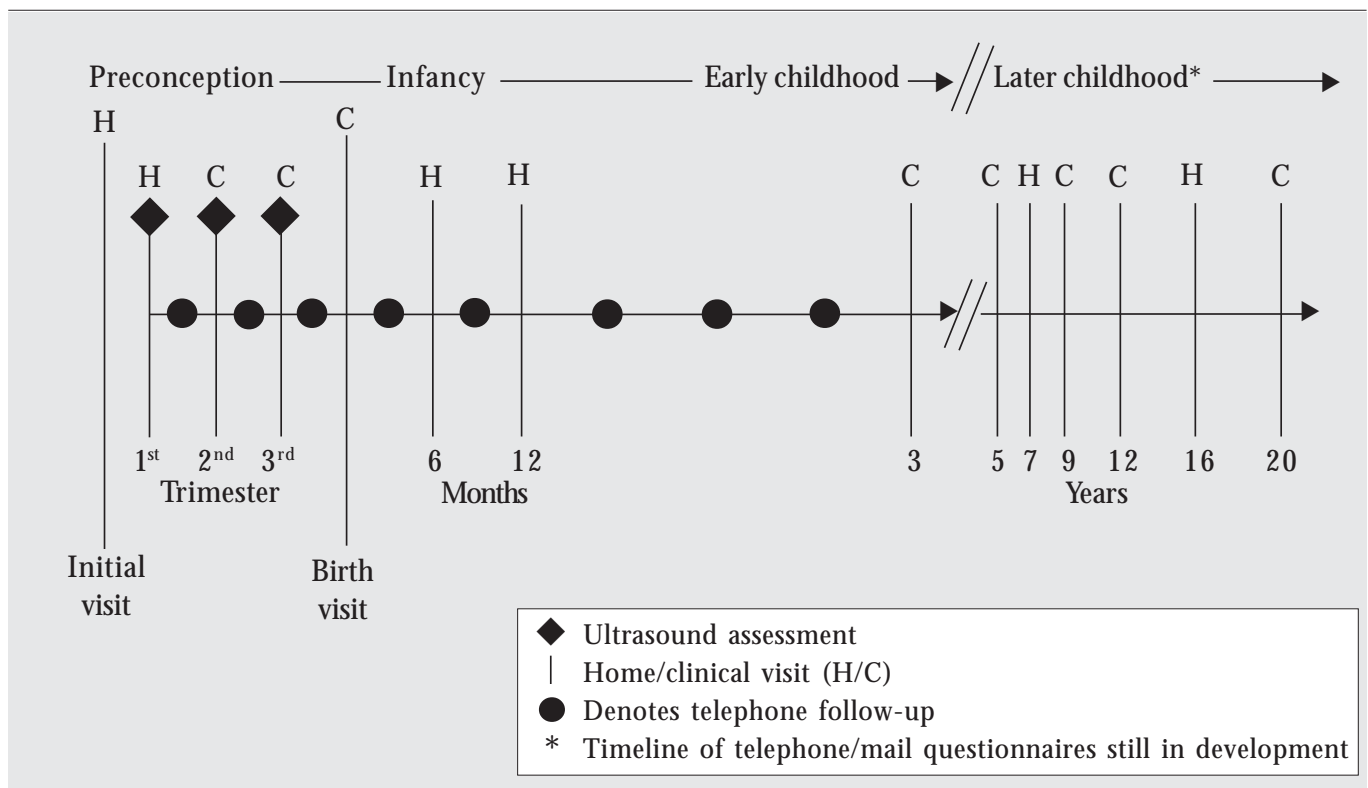

Figure 2. Schedule of visits, NCS. Stars denote ultrasound assessment, while / on the timeline represents home/clinical assessments (denoted by $\mathrm{H} / \mathrm{C}$ ). Circles denote telephone follow-ups, and asterisk denotes components of the timeline for telephone and mail questionnaires that are still under development. 
Table 1. NCS proposed measurements from preconception through pregnancy.

\begin{tabular}{|c|c|c|c|c|c|}
\hline \multirow{2}{*}{ M easurement } & \multicolumn{5}{|c|}{ Preconception } \\
\hline & \multicolumn{2}{|c|}{ Initial Initial follow-up } & \multicolumn{2}{|c|}{ First month Second month } & \multirow{2}{*}{$\begin{array}{c}\text { Fourth month } \\
\text { Phone }\end{array}$} \\
\hline $\begin{array}{l}\text { Location/type } \\
\text { Body composition }\end{array}$ & Home & Mail & Phone & Phone & \\
\hline Length/height & \multicolumn{5}{|c|}{ Body composition } \\
\hline Weight & M & & & & \\
\hline \multicolumn{6}{|l|}{ Head circumference } \\
\hline Arm circumference & M & & & & \\
\hline Waist circumference & M & & & & \\
\hline Hip circumference & M & & & & \\
\hline \multicolumn{6}{|l|}{ Leg length } \\
\hline \multirow{2}{*}{\multicolumn{6}{|c|}{ Ultrasound }} \\
\hline & & & & & \\
\hline Blood pressure & M & & & & \\
\hline \multicolumn{6}{|l|}{ Bioimpedance analysis } \\
\hline \multicolumn{6}{|l|}{ Diet } \\
\hline \multicolumn{6}{|l|}{$\begin{array}{l}\text { Community-based food collection } \\
\text { Food frequency questionnaire }\end{array}$} \\
\hline Self-completion diary & M & M & M & M & M \\
\hline \multicolumn{6}{|l|}{ Activity measures } \\
\hline \multicolumn{6}{|l|}{ Activity questionnaire } \\
\hline \multicolumn{6}{|l|}{ TV viewing } \\
\hline \multicolumn{6}{|l|}{ Time outdoors } \\
\hline \multicolumn{6}{|l|}{ Activity diary } \\
\hline \multicolumn{6}{|l|}{ Biological specimens } \\
\hline Vaginal swabs & M & & & & \\
\hline Blood & M & & & & \\
\hline U rine (self-collected) & & M & & & \\
\hline \multicolumn{6}{|l|}{ Saliva (self-collected) } \\
\hline Hair & M & & & & \\
\hline \multicolumn{6}{|l|}{ Cord blood } \\
\hline \multicolumn{6}{|l|}{ U mbilical cord and placenta } \\
\hline \multicolumn{6}{|l|}{ Meconium } \\
\hline \multicolumn{6}{|l|}{ Breast milk } \\
\hline \multicolumn{6}{|l|}{ Socioeconomic/environmental data } \\
\hline $\begin{array}{l}\text { M other/father education/SES/ } \\
\text { housing }\end{array}$ & M & M & M & M & M \\
\hline $\begin{array}{l}\text { M edical provider visit log } \\
\text { M edical record/chart abstraction }\end{array}$ & M & M & M & M & M \\
\hline
\end{tabular}

it continues

potheses for thestudy, in consultation with thousands of scientists and representatives from community groups and professional organizations. A current list of hypotheses with supporting scientific rationales that were accepted and refined by the Interagency Coordinating Committee [com-posed of senior scientists from NICHD, the National Institute of Environmental H ealth Sciences, the Centers for Disease Control and Pre- vention, and the U.S. Environmental Protection Agency (EPA)] is available on the NCS website ${ }^{64}$.

Childhood obesity is a lead focus of the NCS and is addressed in 6 of 30 core hypotheses. Table 3 presents the gaps of knowledgethat remain with respect to four of these core hypotheses: obesity and insulin resistance from impaired maternal glucosemetabolism; obesity and insulin resistance associated with IU GR; breast-feeding associated 
Table 1. continuation

\begin{tabular}{|c|c|c|c|c|c|c|c|c|}
\hline \multirow[b]{2}{*}{ M easurement } & \multirow[b]{2}{*}{$\begin{array}{c}\text { First } \\
\text { trimester } \\
(<14 \\
\text { weeks })\end{array}$} & \multirow[b]{2}{*}{$\begin{array}{c}\text { First } \\
\text { trimester } \\
\text { follow-up } \\
\text { (<14 weeks) }\end{array}$} & \multirow[b]{2}{*}{$\begin{array}{c}\text { First } \\
\text { trimester } \\
\text { ultrasound }\end{array}$} & \multicolumn{3}{|c|}{ Pregnancy } & \multirow[b]{2}{*}{$\begin{array}{c}\text { Third } \\
\text { trimester } \\
\text { follow-up }\end{array}$} & \multirow[b]{2}{*}{$\begin{array}{c}36 \\
\text { weeks }\end{array}$} \\
\hline & & & & $\begin{array}{l}16-17 \\
\text { weeks }\end{array}$ & $\begin{array}{l}\text { Second } \\
\text { trimester } \\
\text { (22-24 } \\
\text { weeks) }\end{array}$ & $\begin{array}{l}\text { Third } \\
\text { trimester } \\
\text { (28-32 } \\
\text { weeks) }\end{array}$ & & \\
\hline Location/type & Home & Mail & Clinic & Phone & Clinic & Clinic & M ail back & Phone \\
\hline \multicolumn{9}{|l|}{ Body composition } \\
\hline $\begin{array}{l}\text { Weight } \\
\text { Head circumference }\end{array}$ & $M, F$ & & & & M & M & & \\
\hline Arm circumference & $M, F$ & & & & M & M & & \\
\hline Waist circumference & $M, F$ & & & & M & M & & \\
\hline Hip circumference & $M, F$ & & & & M & M & & \\
\hline \multicolumn{9}{|l|}{ Leg length } \\
\hline Skin folds & $M, F$ & & & & M & M & & \\
\hline Ultrasound & $M^{a}$ & & $M^{a}$ & & M & M & & \\
\hline Blood pressure & $M, F$ & & & & M & M & & \\
\hline \multicolumn{9}{|l|}{ Bioimpedance analysis } \\
\hline \multicolumn{9}{|l|}{ Diet } \\
\hline Community-based food collection & $M, N$ & & & & & & & \\
\hline Food frequency questionnaire & & M & & & & & M & \\
\hline Self-completion diary & M & M & M & M & M & M & M & M \\
\hline \multicolumn{9}{|l|}{ Activity measures } \\
\hline \multicolumn{9}{|l|}{ Activity questionnaire } \\
\hline \multicolumn{9}{|l|}{ TV viewing } \\
\hline \multicolumn{9}{|l|}{ Time outdoors } \\
\hline \multicolumn{9}{|l|}{ Activity diary } \\
\hline \multicolumn{9}{|l|}{ Biological specimens } \\
\hline Vaginal swabs & M & & & & & M & & \\
\hline Blood & $M, F$ & & & & & M & & \\
\hline Urine (self-collected) & & $M, F$ & & & & M & & \\
\hline Saliva (self-collected) & & M & & & & & M & \\
\hline Hair & $M, F$ & & & & & M & & \\
\hline \multicolumn{9}{|l|}{ Cord blood } \\
\hline \multicolumn{9}{|l|}{ Umbilical cord and placenta } \\
\hline \multicolumn{9}{|l|}{ Meconium } \\
\hline \multicolumn{9}{|l|}{ Breast milk } \\
\hline \multicolumn{9}{|l|}{ Socioeconomic/environmental data } \\
\hline $\begin{array}{l}\text { Mother/father education/SES/ } \\
\text { housing }\end{array}$ & $M, F$ & M & M & M & M & M & M & M \\
\hline $\begin{array}{l}\text { M edical provider visit log } \\
\text { M edical record/chart abstraction }\end{array}$ & M & M & M & M & M & M & M & M \\
\hline
\end{tabular}

Abbreviations: $F$, data from father; $M$, data from mother; $N$, neighborhood level data; $S E S$, socioeconomic status.

a Data to be abstracted from clinical ultrasound if available; otherwise ultrasound to be performed on mother in clinic setting as part of NCS.

with lower rates of obesity and lower risk of insulin resistance and fiber; and whole grains, high glycemic index, insulin resistance, and obesity.

Table 3 also presents how the NCS will address these gaps through its design. In this re- view, we highlight how the study will pro-vide important new knowledge with regard to two core hypotheses that link factors in the chemical and built environments with childhood obesity. 


\section{Obesity-Related Hypotheses of the NCS}

Impact of neighborhood environment on risk of obesity and insulin resistance

Built environment featuressuch as mixed land use, increased proximity to recreational activities and green space, as well as safety (e.g., low crime rates and perceived traffic safety for pedestrian and bicyclists) have been associated in cross-sec- tional studies with increased physical activity ${ }^{65-67}$ and lower risk of obesity among adults ${ }^{68-70}$. Few studies have examined the impact of the built environment on younger children, and those studies have focused upon circumscribed geographic areas and/or socioeconomically advantaged and ethnically homogeneous communities ${ }^{71}$. Decreased access to healthy eating choices in low socio-economic status neighborhoods has been documented in at least two studies ${ }^{72,73}$. Factors

Table 2. NCS proposed measurements from birth through 3 years of age.

\begin{tabular}{|c|c|c|c|c|c|c|c|}
\hline \multirow[b]{2}{*}{ M easurement } & \multirow{2}{*}{$\begin{array}{c}\text { Birth } \\
\text { Delivery }\end{array}$} & \multirow{2}{*}{ 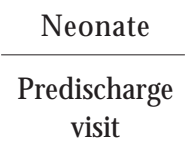 } & \multicolumn{5}{|c|}{ Childhood } \\
\hline & & & 3 months & $\begin{array}{c}6 \\
\text { months }\end{array}$ & $\begin{array}{l}\text { 6-month } \\
\text { follow-up }\end{array}$ & 9 months & 12 months \\
\hline $\begin{array}{l}\text { Location/type } \\
\text { Body composition }\end{array}$ & Hospital & Hospital & Phone & Home & Mail back & Phone & Home \\
\hline $\begin{array}{l}\text { Body composition } \\
\text { Length/height }\end{array}$ & & c & & c & & & \\
\hline Weight & & c & & C & & & C \\
\hline Head circumference & & C & & C & & & C \\
\hline Arm circumference & & C & & C & & & $\mathrm{C}$ \\
\hline Waist circumference & & C & & C & & & $\mathrm{C}$ \\
\hline Hip circumference & & C & & C & & & C \\
\hline Leg length & & & & & & & \\
\hline Skin folds & & C & & C & & & C \\
\hline Ultrasound & & & & & & & \\
\hline Blood pressure & & & & & & & C \\
\hline Bioimpedance analysis & & & & & & & \\
\hline Diet & & & & & & & \\
\hline Community-based food collectior & & & & & & & \\
\hline Food frequency questionnaire & & & & M & & & \\
\hline Self-completion diary & & & & & & & \\
\hline Activity measures & & & & & & & \\
\hline Activity questionnaire & & & & & & & \\
\hline TV viewing & & & & & & & \\
\hline Time outdoors & & & & & & & \\
\hline Activity diary & & & & & & & \\
\hline Biological specimens & & & & & & & \\
\hline Vaginal swabs & & & & & & & \\
\hline Blood & $M, C$ & & & & & & C \\
\hline Urine (self-collected) & M & & & C & & & C \\
\hline Saliva (self-collected) & & & & & $M, F$ & & \\
\hline Hair & & & & C & & & C \\
\hline Cord blood & C & & & & & & \\
\hline Umbilical cord and placenta & M & & & & & & \\
\hline M econium & & C & & & & & \\
\hline Breast milk & & & M & & M & & \\
\hline Socioeconomic/environmental data & & & & & & & \\
\hline $\begin{array}{l}\text { M other/father education/SES/ } \\
\text { housing }\end{array}$ & & & M & $M, F$ & M & $\mathrm{F}$ & M \\
\hline M edical provider visit log & & & M & M & M & M & M \\
\hline Medical record/chart abstraction & & $M, C$ & & & & & \\
\hline
\end{tabular}


Table 2. continuation

\begin{tabular}{|c|c|c|c|c|c|}
\hline \multirow[b]{2}{*}{ M easurement } & \multicolumn{5}{|c|}{ Childhood } \\
\hline & 12-month follow-up & 18 months & 24 months & 30 months & 36 months \\
\hline Location/type & Mail back & Phone & Phone & Phone & Clinic \\
\hline \multicolumn{6}{|l|}{ Body composition } \\
\hline Length/height & & & & & C \\
\hline Weight & & & & & C \\
\hline Head circumference & & & & & C \\
\hline Arm circumference & & & & & C \\
\hline Waist circumference & & & & & $\mathrm{C}$ \\
\hline Hip circumference & & & & & C \\
\hline Leg length & & & & & C \\
\hline Skin folds & & & & & $\mathrm{C}$ \\
\hline \multicolumn{6}{|l|}{ Ultrasound } \\
\hline Blood pressure & & & & & $\mathrm{C}$ \\
\hline Bioimpedance analysis & & & & & C \\
\hline \multicolumn{6}{|l|}{ Diet } \\
\hline Community-based food collection & & $C, N$ & & & $C, N$ \\
\hline Food frequency questionnaire & M & & & & C \\
\hline Self-completion diary & & & & & $\mathrm{C}$ \\
\hline \multicolumn{6}{|l|}{ Activity measures } \\
\hline Activity questionnaire & & & & & C \\
\hline TV viewing & & & & & $\mathrm{C}$ \\
\hline Time outdoors & & & & & $\mathrm{C}$ \\
\hline Activity diary & & & & & C \\
\hline \multicolumn{6}{|l|}{ Biological specimens } \\
\hline \multicolumn{6}{|l|}{ Vaginal swabs } \\
\hline Blood & & & & & $\mathrm{C}$ \\
\hline Urine (self-collected) & & & & & $\mathrm{C}$ \\
\hline Saliva (self-collected) & $\mathrm{C}$ & & & & C \\
\hline Hair & & & & & $\mathrm{C}$ \\
\hline \multicolumn{6}{|l|}{ Cord blood } \\
\hline \multicolumn{6}{|l|}{ Umbilical cord and placenta } \\
\hline \multicolumn{6}{|l|}{ Meconium } \\
\hline Breast milk & & M & & & $\mathrm{C}$ \\
\hline \multicolumn{6}{|l|}{ Socioeconomic/environmental data } \\
\hline $\begin{array}{l}\text { M other/father education/SES/ } \\
\text { housing }\end{array}$ & M & $\mathrm{F}$ & M & M & $M, F$ \\
\hline Medical provider visit log & M & M & M & M & $\mathrm{C}$ \\
\hline M edical record/chart abstraction & & & & & $\mathrm{C}$ \\
\hline
\end{tabular}

Abbreviations: $\mathrm{C}$, data from child; $\mathrm{F}$, data from father; $\mathrm{M}$, data from mother; $\mathrm{N}$, neighborhood level data; SES, socioeconomic statuS.

such as climate and topography have been taken into account infrequently ${ }^{74}$. The effect of after school and summer adult organized programs on obe-sity and insulin resistance is unknown. In the absence of such programs, parents living in urban areas may instruct their children to go directly home from school where indoor activities arelargely limited to watching tele vision and playing computer games in the security of the home.
A systematic review of previous studies of the built environment and childhood obesity identified inconsistencies in measurements of the built environment across studies and cross-sectional designs as major deficits of pre-viousstudies, and noted that these studies rarely studied both diet and physical activ-ity ${ }^{71}$. Because of its focus on community characterization ${ }^{60}$, the NCS will allow more careful identification of those features 


\begin{tabular}{|c|c|c|c|c|}
\hline $\begin{array}{l}\text { Hypothesis } \\
\text { domain }\end{array}$ & $\begin{array}{l}\text { Obesity and } \\
\text { insulin resistance } \\
\text { from impaired } \\
\text { maternal glucose } \\
\text { metabolism }\end{array}$ & $\begin{array}{l}\text { Obesity and insulin } \\
\text { resistance associated with } \\
\text { intrauterine growth } \\
\text { restriction }\end{array}$ & $\begin{array}{l}\text { Breast-feeding associated } \\
\text { with lower rates of obesity } \\
\text { and lower risk of insulin } \\
\text { resistance }\end{array}$ & $\begin{array}{c}\text { Fiber, whole grains, high } \\
\text { glycemic index and obesity, } \\
\text { insulin resistance }\end{array}$ \\
\hline
\end{tabular}

\begin{tabular}{|c|c|c|}
\hline Relevance & $\begin{array}{l}\text { If gestational } \\
\text { diabetes (or } \\
\text { excessive } \\
\text { gestational weight } \\
\text { gain) is } \\
\text { conclusively } \\
\text { demonstrated to } \\
\text { increase risk of } \\
\text { childhood obesity/ } \\
\text { insulin resistance, } \\
\text { then prevention } \\
\text { of overweight } \\
\text { among women of } \\
\text { childbearing age } \\
\text { may be especially } \\
\text { useful in the } \\
\text { prevention of } \\
\text { childhood obesity. }\end{array}$ & $\begin{array}{l}\text { If IU GR is identified as a } \\
\text { preventable cause of obesity, } \\
\text { then prevention of IUGR } \\
\text { could form a major } \\
\text { component of obesity } \\
\text { prevention in the United } \\
\text { States. }\end{array}$ \\
\hline
\end{tabular}

\begin{tabular}{|c|c|c|c|}
\hline $\begin{array}{l}\text { Gaps in } \\
\text { state of } \\
\text { knowledge }\end{array}$ & $\begin{array}{l}\text { M ost studies have } \\
\text { had small sizes, } \\
\text { and have not } \\
\text { completely } \\
\text { differentiated } \\
\text { severe, insulin } \\
\text { dependent and } \\
\text { mild diet- } \\
\text { controlled } \\
\text { gestational } \\
\text { diabetes. Follow- } \\
\text { up has typically } \\
\text { been limited to } \\
\text { the offspring } \\
\text { preschool years, } \\
\text { thus precluding } \\
\text { documentation of } \\
\text { longer term } \\
\text { effects on child } \\
\text { body composition } \\
\text { and metabolic } \\
\text { status. }\end{array}$ & $\begin{array}{l}\text { M ost studies of IU GR and } \\
\text { adult insulin resistance are } \\
\text { based on historical data, and } \\
\text { limited to information } \\
\text { about size at birth and adult } \\
\text { outcomes, with no } \\
\text { information available about } \\
\text { different periods during } \\
\text { prenatal devel opment. } \\
\text { Results have been } \\
\text { contradictory because of } \\
\text { differing definitions of key } \\
\text { dependent and independent } \\
\text { variables, use of different } \\
\text { measurements, and } \\
\text { limitation on the period of } \\
\text { follow up. Many apparent } \\
\text { confounders for this } \\
\text { phenomenon (e.g., levels of } \\
\text { such hormones as cortisol } \\
\text { and insulin-like growth } \\
\text { factors) are likely embedded } \\
\text { in the same causal } \\
\text { framework with IUGR that } \\
\text { underlies the fetal origins of } \\
\text { later life phenomena. Few } \\
\text { studies have serially } \\
\text { measured fetal size and } \\
\text { growth using ultrasound. }\end{array}$ & $\begin{array}{l}\text { If breast-feeding is } \\
\text { protective for childhood } \\
\text { obesity, it is unclear whether } \\
\text { this is due to constituents of } \\
\text { breast milk, metabolic } \\
\text { programming, regulation/ } \\
\text { control of intake by mother } \\
\text { and/or infant, or aspects of } \\
\text { family lifestyle/home } \\
\text { environment that are } \\
\text { different for breast- and } \\
\text { formula-fed infants. } \\
\text { M easurement of family- } \\
\text { level confounders appears to } \\
\text { be extremely important, } \\
\text { and has been lacking in } \\
\text { previous studies of breast- } \\
\text { feeding and obesity. Studies } \\
\text { do suggest that breast- } \\
\text { feeding may only proffer } \\
\text { protection from future risk } \\
\text { of obesity in certain } \\
\text { subpopulations. }\end{array}$ \\
\hline
\end{tabular}

In the absence of proven alternatives, breast-feeding could serve as a lead component of obesity prevention in the United States. Because breastfeeding initiation, exclusivity, and continuation vary greatly by race and ethnic group, breast-feeding could also be a major causative factor for existing and widening disparities in prevalence of childhood obesity and its comorbidities, and targeted interventions among populations where breastfeeding is less frequent would be urgently indicated.

Studies of the role of glycemic indexto date have been limited to small samples, and because the duration of follow-up has typically been brief, the applicability of these findings to broad populations of children has been limited. The contribution of sugary snacks and drinks to current prevalence is unknown, and studies to date have not had the statistical power to isolate for confounding with caloric intake, genetics, physical activity among other factors, or to examine the possibility of specific windows of vulnerability with regard to high glycemic content. Few studies have assessed the impact of whole grains on risk of obesity and insulin resistance in younger children. 


\begin{tabular}{|c|c|c|c|c|}
\hline $\begin{array}{l}\text { Hypothesis } \\
\text { domain }\end{array}$ & $\begin{array}{l}\text { Obesity and insulin } \\
\text { resistance from } \\
\text { impaired maternal } \\
\text { glucose metabolism }\end{array}$ & $\begin{array}{l}\text { Obesity and insulin resistance } \\
\text { associated with intrauterine } \\
\text { growth restriction }\end{array}$ & $\begin{array}{l}\text { Breast-feeding associated with } \\
\text { lower rates of obesity and } \\
\text { lower risk of insulin } \\
\text { resistance }\end{array}$ & $\begin{array}{l}\text { Fiber, whole grains, high } \\
\text { glycemic index and } \\
\text { obesity, insulin } \\
\text { resistance }\end{array}$ \\
\hline $\begin{array}{l}\text { Unique } \\
\text { capacity of } \\
\text { the National } \\
\text { Children's } \\
\text { Study }\end{array}$ & $\begin{array}{l}\text { A cohort of } \\
100,000 \text { is adequate } \\
\text { for assessment of } \\
\text { main effects for } \\
\text { exposures at least as } \\
\text { prevalent as } \\
\text { adolescent type } 2 \\
\text { diabetes. It is } \\
\text { certainly not too } \\
\text { large, as power } \\
\text { becomes marginal } \\
\text { for main effects } \\
\text { within sex and } \\
\text { race/ethnicity- } \\
\text { specific strata, } \\
\text { when exposures are } \\
\text { as uncommon as } \\
\text { gestational diabetes, } \\
\text { even for relatively } \\
\text { common outcomes } \\
\text { such as obesity, for } \\
\text { odds ratios < 1.5. }\end{array}$ & $\begin{array}{l}\text { The National Children's } \\
\text { Study design will measure } \\
\text { maternal nutritional status } \\
\text { and fetal stressors at different } \\
\text { periods during prenatal } \\
\text { development; fetal growth } \\
\text { measured with serial } \\
\text { ultrasounds; fetal body } \\
\text { composition; size and body } \\
\text { composition at birth and } \\
\text { throughout childhood, } \\
\text { adolescence and early } \\
\text { adulthood; dietary intake of } \\
\text { mother during pregnancy and } \\
\text { the offspring postnatally; and } \\
\text { key hormonal levels in the } \\
\text { mother and child. } \\
\text { Information about family } \\
\text { factors (e.g., sibling birth size, } \\
\text { body composition of other } \\
\text { family members, maternal } \\
\text { history of birth size) will } \\
\text { better control confounding. }\end{array}$ & $\begin{array}{l}\text { Prospective report of breast- } \\
\text { feeding, and use of a metric } \\
\text { that incorporates duration of } \\
\text { breast-feeding with the } \\
\text { percentage of intake derived } \\
\text { from breast milk will settle } \\
\text { existing debates about the } \\
\text { protective benefit offered by } \\
\text { breast-feeding. Collection of } \\
\text { genetic data will provide an } \\
\text { opportunity to identify } \\
\text { whether genetic or other } \\
\text { factors influence the } \\
\text { relationship between breast- } \\
\text { feeding and obesity/insulin } \\
\text { resistance among whites and } \\
\text { nonwhites. The N CS will } \\
\text { follow a large multiethnic } \\
\text { population and have the } \\
\text { power to assess the influence } \\
\text { of cultural factors on breast- } \\
\text { feeding and formula } \\
\text { supplementation. }\end{array}$ & $\begin{array}{l}\text { The National Children's } \\
\text { Study offersof the } \\
\text { National strong } \\
\text { statistical power to } \\
\text { examine theChildren's } \\
\text { Study role of factors in } \\
\text { the dietary maternal } \\
\text { gestational diabetes, and } \\
\text { environment of } \\
\text { children, and is the first } \\
\text { outcomes at least as } \\
\text { prevalent as large cohort } \\
\text { study with the potential } \\
\text { to use the knowledge } \\
\text { produced by the H uman } \\
\text { Genome Project to } \\
\text { examine the role of } \\
\text { genetic vulnerability in } \\
\text { modifying the risk } \\
\text { posed by factors such as } \\
\text { glycemic index. }\end{array}$ \\
\hline
\end{tabular}

of neighbor-hoods that affect physical activity and diet, such as proximity to play spaces, availability of healthy food stores, and neighborhood walkability.

The NCS represents a major opportunity to explore the role of specific aspects of the neighborhood environment at different periods in a child's development. Access to safeplay spaces near a child's home, for example, may be especially protective against obesity during the early school years, but less so during ado-lescence. The design of the NCS capitalizes on thelife-courseapproach and allows for separate analyses of the impact of certain factors on the development of obesity or increase in adiposity within certain time periods. Simultaneous collection of socioeconomic and genetic data as well as measures of diet and physical activity (Tables 1 and 2) will permit careful distinction of the role of certain environmental risk factors during each window of vulnerability.
Chemical environmental agents and the endocrine system

Theimpact of EDs on humans was first identified by Herbst and Bern, who observed eight cases of clear cell adenocarcinoma of the vagina in young women who had been exposed in utero to diethylstilbestrol (DES), a synthetic estrogen prescribed to pregnant women in the1950s, 1960s, and 1970 s to prevent miscarriage ${ }^{75}$. Prenatal exposure to DES has been found subsequently to induce obesity in an animal mode ${ }^{23}$. Identification of endocrine-disrupting chemicals has been limited by the lack of toxicity testing data available for many chemicals in widespread use ${ }^{76}$.

Because so few chemicals have been tested for their toxicity, the possibility exists that other chemicals besides DES influence somatic growth and obesity ${ }^{48,50}$. O ne potential endocrine-disrupting chemical, bisphenol A (BPA), is used to manufac- 
ture polycarbonate resin in the coatings of food and beverage containers ${ }^{77}$. Exposure to BPA, phthalates, and other EDs is widespread in American children ${ }^{78}$, and animal studies increasingly suggest the potential for toxicity at current levels of exposure ${ }^{79}$. In vitro studies havefound that BPA induces fibroblast differentiation into adipocytes ${ }^{80}$. Animal studies have found that BPA affects glucosetransport in fat cells ${ }^{81}$. BPA al so disrupts glucagon secretion in intact Langerhans cells at nanomolar levels ${ }^{82}$. These studies raise the possibility that BPA could bearisk factor for the development of obesity, a question undergoing examination in at least one Center for Children's Environmental $\mathrm{H}$ ealth and Disease Prevention ${ }^{83}$.

Phthalates are used in a variety of per-sonal care products such as shampoos and in the synthesis of polyvinyl chloride ${ }^{34}$. Phthalates have been documented consistently in animal studies to have antiandrogenic effects ${ }^{85-87}$. Cohort stud-ies have begun to assess for potential effects in humans and suggest susceptibility at lower levels of exposurethan those documented to have effects in animals. It is hypothesized that the most severe effects may be associated with exposures in prenatal and early postnatal life. Decreases in anogenital distance among infant males have been associated with el evated urinary phthalatelevels during pregnancy ${ }^{88}$, and breast milk levels of monoester phthal ates have been associated with higher serum hormone binding globulin levels and luteinizing hormoneto freetestosteroneratios ${ }^{89}$. Diminished sperm motility has been identified among exposed men $^{90-92}$, and low-molecular-weight phthalates have been associated with increased birth weight and longer duration of gestation in at least one birth cohort ${ }^{83}$. Although few studies haveanalyzed the impact of phthalate exposure on increased adiposity in children, analysis of the 1999-2002 $\mathrm{N}$ ational $\mathrm{H}$ ealth and Nutrition Examination Survey has identified increases in urinary phthalate levelsamong men with increased waist circumference and homeostatic model assessment, a measure of insulin resistance $e^{93}$.

Lack of accurate information on thelevel and timing of past exposures to EDs has been the principal limitation of most previous studies of the potential human impacts of EDs. This limitation will be directly addressed by the prospective design of the NCS. In the NCS, exposures to chemicals will bemeasured during pregnancy, in breast milk, and in the perinatal period before the appearance of health effects. The large sample size will facilitateinvestigation of possiblelinks between low-prevalence endocrine-disruptor exposures and health outcomes, and state-of-the-art laboratory assessment of chemical exposures will further sharpen the study's ability to discern effects of exposures to EDs. The large sample size will also permit study of genetic polymor-phisms and gene-environment interactions, which may unearth individual differences in susceptibility to EDs. As new EDsareidenti-fied, specimens can be withdrawn from the NCS repository to analyze their content for appropriate biomarkers to assess whether these ED s may be risk factors in the development of obesity ${ }^{94}$.

\section{Conclusion}

The NCS presents previously unrealized opportunities for the identification of risk factors for childhood obesity, and for their subsequent elimination through prevention. Just as the Framingham $\mathrm{H}$ eart Study provided health care providers with hitherto novel information on risk factors for cardiovascular disease that enabled them to offer evidence-based advice to limit smoking, reduce the intake of fatty foods, and control hypertension, the NCS will suggest interventions that can be used to pre-vent obesity by communities, policy makers, and child health providers. A major strength of thestudy is that it will be representative of American children. It is anticipated, for exam-ple, that $>20,000$ children in thecohort will be Hispanic, permitting examination of unique risk factors among a subgroup that has been disproportionately affected by the epidemic.

The hypotheses presented in this review cover only a small percentage of the findings likely to emerge from the NCS. The core NCS hypotheses are dynamic, and as the study is implemented, new questions will emerge and result in modifications to the study protocol. Others may beclearly answered through the NCS or other studies, or becomeoutdated as the wholebody of knowledge adjusts the direction of inquiry. For some areas of inquiry where the science is in relatively nascent stages, the major benefits to be gained from the study derive from its hypothesis-generating nature. The NCS will provide a major opportunity to confirm putativegenetic links identified in other studies through thestudy of genetic sequences of children and their families ${ }^{95}$. As new putative EDs are identified, subsamples of biospecimens stored at the NCS Specimen Repository can be rapidly analyzed to test for associations in a large-scale cohort that represents the population of U.S. children. 
Of course, no observational study by itself can demonstrate causality. The NCS will identify risk factors for which causality may be suggested on the basis of strength, consistency, temporality, biological gradient, and plausibility. Findings from the NCS will prompt further interventions such as randomized con-trolled trials, policy interventions, and other initiatives that will confirm or refute the role of identified risk factors in the development of obesity and its associated comorbidities.

The life-course approach underlying the design of the NCS may very well lead to delineating the duration and impact of environmental, behavioral, and social exposures on risk for obesity. No study will havefollowed women from preconception and subsequently followed their children at such frequent intervals early in childhood and then through adolescence and young adulthood. The NCS will collect an array of biospecimens, dietary and physical activity data, and social and chemical environmental factors on all 100,000 children for all proposed data collection time points, whereas other cohorts have collected more limited data at each time point or collected complete data on a smaller sample.

A major challenge of the NCS will be to overcomethedifficulties in measuring physical activity, diet, and anthropometry in children that have bedeviled past studies. Limitations of reliability and validity do exist with food-frequency questionnaire ${ }^{96,97}$ and other instruments commonly used to measure dietary intake, although promising alternatives have been developed for populations in which past instruments have not proven reliable $e^{98}$. The vagaries of collecting information on physical activity by ques-tionnaire are well documented ${ }^{99}$, but accelerometry and other measur-ing techniques are increasingly promising in their precision and application ${ }^{100,101}$. BMI is not a perfect measure of adiposity ${ }^{102}$, and dual-absorption X-ray absorptiometry has been strongly correlated with cardiovascular disease factors in children ${ }^{103}$. Bioimpedance analysis and skinfold thickness are increasingly used to measure adiposity ${ }^{104,105}$.

These challenges will not be easily dismissed, and the opportunity is ripe for contributions from the obesity research community to ensure that the best questionnaires and measurement approaches are utilized in an efficient and costeffective way. At this time, the protocol has been finalized only for the seven Vanguard (pilot) locations, and even for thoselocations only through birth. The NCS also offers major opportunities to study the validity and reliability of alterative mea-surement approachesthrough adjunct studies in collaboration with existing study centers. These studies may use the full or a subsample of the study cohort, with the caveat that pro-posed new data collection not imposeundueadditional burden on study participants or additional financial burden on the study.

The NCS will also trigger ancillary and follow-up studies and provide the next generation of obesity researchers opportunities to apply for funding ${ }^{106}$. The NCS will make public use, deidentified data sets available in accordance with federal privacy regulations.

Previous cohort studies of cardiovascular risk have plowed the terrain to identify major risk factors and allow the NCS to close in on solutions to theepidemic of childhood obesity. However, they have also demonstrated that these relationships are complex and temporally dependent, making a large longitudinal cohort study beginning in the prenatal period essential. The NCS thus offers us great hope in combating the obesity epidemic among America's children.

\section{Acknowledgements}

The authors are investigators in the Queens, New York, and Waukesha County, Wisconsin, Vanguard Centers and the Coordinating Center of the National Children's Study. This project has been funded in wholeor in part with federal funds from the $\mathrm{N}$ ational Institute of $\mathrm{Child} \mathrm{H}$ ealth and Human Development, National Institutes of $\mathrm{H}$ ealth, under contracts NICHD HHSN 275200503411C/N 01-HD-5-3411. 


\section{References}

1. Ogden $C L$, Carroll MD, Curtin LR, MCDowell MA, Tabak CJ, Flegal KM. Prevalence of overweight and obesity in the United States, 1999-2004. JAM A 2006; 295(13):1549-1555.

2. Strauss RS, Pollack HA. Epidemic increase in childhood overweight, 1986-1998. JAMA 2001; 286(22):2845-2848.

3. Troiano RP, Flegal KM, Kuczmarski RJ, Campbell $S M$, Johnson CL. Overweight prevalence and trends for children and adolescents. The National $\mathrm{H}$ ealth and Nutrition Examination Surveys, 1963 to 1991. Arch Pediatr Adolesc M ed 1995; 149(10):1085-1091.

4. Ogden CL, Carroll MD, Flegal KM. High body mass index for age among US children and adolescents, 2003-2006. JAM A 2008; 299(20):2401-2405.

5. Bibbins-Domingo K, Coxson P, Pletcher MJ, Lightwood J, Goldman L. Adolescent overweight and future adult coronary heart disease. N ew Engl J M ed 2007; 357(23):2371-2379.

6. Lee JM, Okumura MJ, Freed GL, M enon RK, Davis M M. Trends in hospitalizations for diabetes among children and young adults: United States, 19932004. Diabetes Care 2007; 30(12):3035-3039.

7. Bjørge T, Engeland A, Tverdal A, Smith GD. Body mass index in adolescence in relation to causespecific mortal-ity: a follow-up of 230,000 Norwegian adolescents. Am J Epidemiol 2008; 168:30-37.

8. Olshansky SJ, Passaro D, Hershow R, Layden J, Carnes BA, Brody J, Hayflick L, Butler RN, Allison $D B$, Ludwig DS. A possible decline in life expectancy in the United States in the 21st century. N Engl J M ed 2005; 352:1138-1145.

9. Summerbell CD, Waters E, Edmunds LD, Kelly $S$, Brown T, Campbell KJ. Interventions for preventing obe-sity in children [Review]. Cochrane Database Syst Rev 2005; 3:CD 001871.

10. M eaney MJ, Seckl JR. Glucocorticoid programming Ann NY Acad Sci 2004; 1032:63-84.

11. Moll PP, Burns TL, Lauer RM. The genetic and environmental sources of body mass index variability: the Muscatine Ponderosity Family Study. Am J Hum Genet 1991; 49(6):1243-1255.

12. Ong KK, Northstone K, Wells JC, Rubin C, Ness $A R$, Golding J, Dunger DB. Earlier mother's age at menarche predicts rapid infancy growth and childhood obesity. PLoS M ed 2007; 4(4):e132.

13. [Anonymous.] Improving individual and community health through health promotion strategies: local case study-Joseph Thompson and the Body $M$ ass Index Assessment Project in Arkansas. In: Moments in Leadership: Case Studies in Public $\mathrm{H}$ ealth Policy and Practice (Debuono B, Gonzalez $A R$, and Rosenbaum S, eds). New York: Pfizer Inc.; 2007. p. 127-132.

14. Ewing R, Schmid T, Killingsworth R, Zlot A, Raudenbush $\mathrm{S}$. Relationship between urban sprawl and physical activity, obesity, and morbidity. Am J Health Promot 2003; 18(1):47-57.

15. Frumkin H, Frank L, Jackson R. Urban Sprawl and Public Health: Designing, Planning, and Building for Healthy Communities. Washington, D.C.: Island Press; 2004.
16. Gortmaker SL, Must A, Sobol AM, Peterson K, Colditz GA, Dietz WH. Television viewing as a cause of increasing obesity among children in the United States, 1986-1990. Arch Pediatr Adolesc M ed 1996; 150(4):356-362.

17. Lobstein T, Dibb S. Evidence of a possible link between obesogenic food advertising and child overweight. O bes Rev 2005; 6(3):203-208.

18. Bo S, M enato G, Gallo ML, Bardelli C, Lezo A, Signorile A, Gambino R, Cassader M, M assobrio M, Pagano G. Mild gestational hyperglycemia, the metabolic syndrome and adverse neonatal outcomes. Acta Obstet Gynecol Scand 2004; 83(4):335-340.

19. Dabelea D, Hanson RL, Lindsay RS, Pettitt DJ, Imperatore G, Gabir M M, Roumain J, Bennett PH, Knowler WC. Intrauterine exposure to diabetes conveys risks for type 2 diabetes and obesity: a study of discordant sibships. Diabetes 2000; 49(12):2208-2211.

20. Bergmann KE, Bergmann RL, von Kries R, Böhm $O$, Richter R, Dudenhausen JW, Wahn U. Early determinants of child-hood overweight and adiposity in a birth cohort study: role of breast-feeding. Int J Obes 2003; 27:162-172.

21. Oken E, Levitan EB, Gillman MW. Maternal smoking dur-ing pregnancy and child overweight: systematic review and meta-analysis. Int J 0 bes 2008; 32:201-210.

22. Oken E, Taveras EM, Kleinman KP, Rich-Edwards JW, Gillman M W. Gestational weight gain and child adiposity at age 3 years. Am J Obstet Gynecol 2007; $196(4): 322-322$.

23. N ewbold RR, Padilla-Banks E, Snyder RJ, Phillips $T M$, Jefferson WN. Developmental exposure to endo-crine disruptors and the obesity epidemic. Reprod Toxicol 2007; 23(3):290-296.

24. Reilly JJ, Armstrong J, Dorosty AR, Emmett PM, Ness A, Rogers I, Steer C, Sherriff A; Avon Longitudinal Study of Parents and Children Study Team. Early life risk factors for obesity in childhood: cohort study. BMJ 2005; 330:1357.

25. Taveras EM, Rifas-Shiman SL, Oken E, Gunderson EP, Gillman M W. Short sleep duration in infancy and risk of childhood overweight. Arch Pediatr Adolesc M ed 2008; 162(4):305-311.

26. Berkey CS, Rockett HRH, Field AE, Gillman MW, Frazier AL, Camargo CA, Colditz GA. Activity, dietary intake, and weight changes in a longitudinal study of preadolescent and adolescent boys and girls. Pediatrics 2000; 105:e56.

27. Demerath EW, Li J, Sun SS, Chumlea WC, Remsberg KE, Czerwinski SA, Towne B, Siervogel RM . Fifty-year trends in serial body mass index during adolescence in girls: the Fels Longitudinal Study. Am J Clin Nutr 2004; 80(2):441-446.

28. Freedman DS, Khan LK, Serdula MK, Dietz WH, Srinivasan SR, Berenson GS. The relation of childhood BMI to adult adiposity: the Bogalusa Heart Study. Pediatrics 2005; 115(1):22-27.

29. Gordon-Larsen $P, N$ elson M C, Page P, Popkin BM . Inequality in the built environment underlies key health disparities in physical activity and obesity. Pediatrics 2006; 117(2):417-424. 
30. Guo SS, Wu W, Chumlea WC, Roche AF. Predicting over-weight and obesity in adulthood from body mass index values in childhood and adolescence. Am J Clin Nutr 2002; 76(3):653-658.

31. Lake JK, Power C, Cole TJ. Child to adult body mass index in the 1958 British birth cohort: associations with parental obesity. Arch Dis Child 1997; 77(5):376-381.

32. Lauer RM, Clarke WR, Burns TL. Obesity in childhood: the Muscatine Study. Zhonghua M in Guo Xiao Er Ke Yi Xue Hui Za Zhi 1997; 38(6):432-437.

33. Nader PR, O'Brien M, Houts R, Bradley R, Belsky J, Crosnoe R, Friedman S, M ei Z, Susman EJ; National Institute of Child $\mathrm{H}$ ealth and Human Development Early Child Care Research Network. Identifying risk for obesity in early childhood. Pediatrics 2006; 118(3):e594-601.

34. Nelson M C, Gordon-Larsen P, Song Y, Popkin BM Built and social environments associations with adolescent overweight and activity. Am J Prev Med 2006; 31(2):109-117.

35. Parsons TJ. Fetal and early life growth and body mass index from birth to early adulthood in 1958 British cohort: longitudinal study. BMJ 2001; 323(7325):1331-1335.

36. Siervogel RM, Wisemandle W, Maynard LM, Guo SS, Chumlea WC, Towne B. Lifetime overweight status in relation to serial changes in body composition and risk factors for cardiovascular disease: The Fels Longitudinal Study. O bes Res 2000; 8(6):422-430.

37. Strauss RS, Knight J. Influence of the home environ-ment on the development of obesity in children. Pediatrics 1999; 103(6):e85.

38. Thompson DR, Obarzanek E, Franko DL, Barton BA, Morrison J, Biro FM, Daniels SR, StriegelMoore RH. Childhood overweight and cardiovascular disease risk factors: The National H eart, Lung, and Blood Institute Growth and Health Study. J Pediatr 2007; 150(1):18-25.

39. Ben-Shlomo Y, Kuh D. A life course approach to chronic disease epidemiology: conceptual models, empirical chal-lenges and interdisciplinary perspectives. Int J Epidemiol 2002; 31:285-293.

40. Barker DJ, Osmond C. Infant mortality, childhood nutrition, and ischaemic heart disease in England and Wales. Lancet 1986; 1(8489):1077-1081.

41. Lynch J, Smith GD. A life course approach to chronic disease epidemiology. Annu Rev Public Health 2005; 26(1):1-35.

42. Gillman MW. A life course approach to overweight and obesity. In: A Life Course Approach to Chronic Diseases Epidemiology (Kuh D, Ben-Shlomo Y, eds). Oxford, UK: Oxford University Press; 2004.

43. James SA, Fowler-Brown A, Raghunathan TE, Van Hoewyk J. Life-course socioeconomic position and obesity in African American women: The Pitt County Study. Am J Public Health 2006; 96:554-560.

44. Novak M, Ahlgren C, Hammarström A. A lifecourse approach in explaining social inequity in obesity among young adult men and women. Int J Obes 2006; 30:191-200.

45. Landrigan PJ, Sonawane B, Butler RN, Trasande L, Callan R, Droller D. Early environmental origins of neurode-generative disease in later life. Environ Health Perspect 2005; 113:1230-1233.
46. National Research Council. Pesticides in the Diets of Infants and Children. Washington, D.C.: National Academy Press; 1993.

47. Wolff MS, Britton JA, Boguski L, Hochman S, Maloney N, Serra N, Liu Z, Berkowitz G, Larson S, Forman J. Environmental exposures and puberty in innercity girls. Environ Res 2008; 107(3):393-400.

48. Bhathena SJ, Velasquez MT. Beneficial role of dietary phytoestrogens in obesity and diabetes. Am J Clin Nutr 2002; 76(6):1191-1201.

49. Enan E, Lasley B, Stewart D, Overstreet J, Vandevoort CA. 2, 3, 7, 8-Tetrachlorodibenzo-p-dioxin (TCDD) modu-lates function of human luteinizing granulosa cells via CAM P signaling and early reduction of glucose transport-ing activity. Reprod Toxicol 1996; 10(3):191-198.

50. Rubin BS, Murray MK, Damassa DA, King JC, Soto $A M$. Perinatal exposure to low doses of bisphenol A affects body weight, patterns of estrous cyclicity, and plasma LH levels. Environ H ealth Perspect 2001; 109:675-680.

51. Kim J, Peterson KE, Scanlon KS, Fitzmaurice GM, Must A, Oken E, Rifas-Shiman SL, Rich-Edwards JW, Gillman MW. Trends in overweight from 1980 through 2001 among preschool-aged children enrolled in a health mainte-nance organization. Obesity (Silver Spring) 2006; 14(7):1107-1112.

52. Freedman DS, Khan LK, Serdula MK, Ogden CL, Dietz WH. Racial and ethnic differences in secular trends for childhood BMI, weight, and height. Obesity (Silver Spring) 2006; 14(2):301-308.

53. Kipke MD, Iverson E, Moore D, Booker C, Ruelas $V$, Peters $A L$, Kaufman F. Food and park environments: neighbor-hood-level risks for childhood obesity in East Los Angeles. J Adolesc H ealth 2007; 40(4):325-333.

54. Glass TA, M cAtee MJ. Behavioral science at the cross-roads in public health: extending horizons, envisioning the future. Soc Sci M ed 2006; 62(7):16501671.

55. Kroke A, Hahn S, Buyken AE, Liese AD. A comparative evaluation of two different approaches to estimating age at adiposity rebound. Int J O bes 2006; 30:261-266.

56. Wisemandle W, Maynard LM, Guo SS, Siervogel RM. Childhood weight, stature, and body mass index among never overweight, early-onset overweight, and late-onset overweight groups. Pediatrics 2000; 106(1):e14.

57. OIsen J, M elbye M, OIsen SF, Sorensen TIA, Aaby P, Nybo Andersen AM, . The Danish National Birth Cohort-its background, structure and aim. Scand J Public Health 2001; 29(4):300-307.

58. Children's Health Act of 2000. Public Law 106-310.

59. Branum AM, Collman GW, Correa A, Keim SA, Kessel W, Kimmel CA, Taxbøl D, Hansen KD, Juhl $M$, Schow TB, Sørensen HT, Andresen J, M ortensen EL, Olesen AW, Søndergaard C. The National Children's Study of environmental effects on child health and development. Environ Health Perspect 2003; 111:642-646. 
60. Landrigan PJ, Trasande L, Thorpe LE, Gwynn C, Lioy PJ, D'Alton ME, Lipkind HS, Swanson J, Wadhwa PD, Clark EB, Rauh VA, Perera FP, Susser E. The National Children's Study: a 21-year prospective study of 100,000 American children. Pediatrics 2006; 118(5):2173-2186.

61. Trasande L, Landrigan PJ. The National Children's Study: a critical national investment. Environ $\mathrm{H}$ ealth Perspect 2004; 112:A789-A790.

62. Trasande L, Cronk CE, Leuthner SR, H ewitt JB, Durkin MS, McElroy JA, Anderson HA, Landrigan PJ. The National Children's Study and the children of Wisconsin. WMJ 2006; 105(2):50-54.

63. Strauss W LJ, Menkedick J, Ryan L, Pivetz T, M CMillan N, Pierce B, Rust S. White Paper on Evaluation of Sampling Design Options for the National Children's Study. [accessed 1 M ay 2007]. Available from: http://www.nationalchildrensstudy.gov/research/analytic reports/upload/Executive-Summary-for-the-W hite-Paper-on-Evaluation-of-Sampling-Design-O ptions-for-the- $\mathrm{N}$ ational-Children-sStudy.pdf

64. NCS. National Children's Study Home Page. [accessed 1 July 2008]. Available from: www.national childrensstudy.gov

65. Cervero R, Duncan M. Walking, bicycling, and urban landscapes: evidence from the San Francisco Bay Area. Am J Public H ealth 2003; 93(9):1478-1483.

66. Ellaway A, M acintyre S, Bonnefoy X. Graffiti, greenery, and obesity in adults: secondary analysis of European cross sectional survey. BMJ 2005; 331(7517): 611-612.

67. Li F, Fisher KJ, Brownson RC, Bosworth M. Multilevel modelling of built environment characteristics related to neighbourhood walking activity in older adults. BMJ 2005; 59(7):558-564.

68. Ewing R, Brownson RC, Berrigan D. Relationship between urban sprawl and weight of U nited States youth. Am J Prev M ed 2006; 31(6):464-474.

69. Frank LD, Andresen MA, Schmid TL. Obesity relationships with community design, physical activity, and time spent in cars. Am J Prev Med 2004; 27(2):87-96.

70. Lopez R. Urban sprawl and risk for being overweight or obese. Am J Public Health 2004; 94:15741579.

71. Papas M A, Alberg AJ, Ewing R, Helzlsouer KJ, Gary $T L, K$ lassen AC. The built environment and obesity. Epidemiol Rev 2007; 29(1):129-143.

72. Galvez M P, Morland K, Raines C, Kobil J, Siskind J, Godbold J, Brenner B. Race and food store availability in an inner-city neighbourhood. Public $\mathrm{H}$ ealth Nutr 2008; 11(6):624-631.

73. Morland K, Diez Roux AV, Wing S. Supermarkets, other food stores, and obesity: the Atherosclerosis Risk in Communities Study. Am J Prev Med 2006; 30(4):333-339.

74. Timperio A, Ball K, Salmon J, Roberts R, GilesCorti B, Simmons D, Baur LA, Crawford D. Personal, family, social, and environmental correlates of active commuting to school. Am J Prev Med 2006; $30(1): 45-51$
75. Bern H. The fragile fetus. In: Chemically-Induced Alteration in Sexual and Functional Development: The Wildlife/Human Connection (Colborn T, Clement C, eds). Princeton, NJ: Princeton Scientific Publishing; 1992. p. 9-15.

76. U.S. EPA. Chemical Hazard Data Availability Study: What Do We Really Know About the Safety of High Production Volume Chemicals? Washington, D.C.: Office of Pollution Prevention and Toxics, U.S. Environmental Protection Agency; 1998.

77. Brotons J. Xenoestrogens released from lacquer coatings in food cans. Environ Health Perspect 1995; 103:608-612.

78. Centers for Disease Control and Prevention. Third $\mathrm{N}$ ational Report on Human Exposure to Environmental Chemicals. Atlanta, GA: Centers for Disease Control and Prevention; 2005.

79. Vom Saal FS, Hughes C. An extensive new literature con-cerning low-dose effects of bisphenol A shows the need for a new risk assessment. Environ $\mathrm{H}$ ealth Perspect 2005; 113:926-934.

80. M asuno H, Kidani T, Sekiya K, Sakayama K, Shiosaka T, Yamamoto H, Honda K. Bisphenol A in combination with insulin can accelerate the conversion of 3T3-L1 fibroblasts to adipocytes. J Lipid Res 2002; 43(5):676-684.

81. Sakurai K, Kawazuma M, Adachi T, Harigaya T, Saito $Y$, Hashimoto N, Mori C. Bisphenol A affects glucose transport in mouse 3T3-F442A adipocytes. Br J Pharmacol 2004; 141:209-214.

82. Alonso-M agdalena $P$, Laribi $O$, Ropero $A B$, Fuentes E, Ripoll C, Soria B, Nadal A. Low doses of bisphenol $A$ and dieth-ylstilbestrol impair $\mathrm{Ca} 2+$ signals in pancreatic a-cells through a nonclassical membrane estrogen receptor within intact islets of Langerhans. Environ Health Perspect 2005; 113:969-967.

83. Wolff MS, Engel SM, Berkowitz GS, Ye X, Silva MJ, Zhu C, Wetmur J, Calafat AM. Prenatal phenol and phthalate exposures and birth outcomes. Environ Health Perspect 2008; 116:1092-1097.

84. Sathyanarayana S. Phthalates and children's health. Curr Probl Pediatr Adolesc H ealth Care 2008; 38(2):3449.

85. Bell FP. Effects of phthalate esters on lipid metabolism in various tissues, cells and organelles in mammals. Environ Health Perspect 1982; 45:41-50.

86. Fisher JS. Environmental anti-androgens and male reproductive health: focus on phthalates and testicular dysgenesis syndrome. Reproduction 2004; 127(3):305-315.

87. Parks LG, O stby JS, Lambright CR, Abbott BD, Klinefelter GR, Barlow NJ, Gray Jr. LE. The plasticizer diethylhexyl phthalate induces malformations by decreasing fetal testosterone synthesis during sexual differentiation in the male rat. Toxicol Sci 2000; 58:339-349.

88. Swan $S H, M$ ain KM, Liu F, Stewart $S L$, Kruse RL, Calafat AM, M ao CS, Redmon JB, Ternand CL, Sullivan S, Teague JL, Study for Future Families Research Team. Decrease in anogenital distance among male infants with prenatal phthalate exposure. Environ Health Perspect 2005; 113:1056-1061. 
89. Main KM, Mortensen GK, Kaleva M M, Boisen KA, Damgaard IN, Chellakooty M, Schmidt IM, Suomi $A M$, Virtanen $H E$, Petersen DV, Andersson AM, Toppari J, Skakkebaek NE. Human breast milk con-tamination with phthalates and alterations of endogenous reproductive hormones in infants three months of age. Environ Health Perspect 2006; 114:270-276.

90. Duty SM, Silva MJ, Barr DB, Brock JW, Ryan L, Chen Z, Herrick RF, Christiani DC, Hauser R. Phthalate exposure and human semen parameters. Epidemiology 2003; 14(3):269-277.

91. Hauser R. The environment and male fertility: re cent research on emerging chemicals and semen quality. Semin Reprod Med 2006; 24(3):156-167.

92. Hauser R, M eeker JD, Duty S, Silva MJ, Calafat AM . Altered semen quality in relation to urinary concentrations of phthalate monoester and oxidative metabolites. Epidemiology 2006; 17(6):682-691.

93. Stahlhut RW, van Wijngaarden E, Dye TD, Cook S, Swan SH. Concentrations of urinary phthalate metabolites are associated with increased waist circumference and insu-lin resistance in adult US males. Environ $\mathrm{H}$ ealth Perspect 2007; 115:876-882.

94. Landrigan P, Garg A, Droller DBJ. Assessing the effects of endocrine disruptors in the National Children's Study. Environ Health Perspect 2003; 111:16781682.

95. Landrigan PJ, Trasande L, Swanson JM. Genetics, altru-ism, and the National Children's Study. Am J M ed Genet A 2008; 146(3):294-296.

96. Coates RJ, Monteilh CP. Assessments of food-frequency questionnaires in minority populations. Am J Clin Nutr 1997; 65(suppl 4):1108S-1115S.

97. Teufel NI. Development of culturally competent food-frequency questionnaires. Am J Clin Nutr 1997; 65(4 suppl): 1173S-1178S.

98. Yaroch A, Resnicow KEN, Davis M, Davis A, Smith $M$, Khan LK. Development of a modified picturesort food fre-quency questionnaire administered to low-income, over-weight, African-American adolescent girls. J Am Dietetic Assoc 2000; 100(9):1050-1056.

99. Kohl HW, Fulton JE, Caspersen CJ. Assessment of physi-cal activity among children and adolescents: a review and synthesis. Prev M ed 2000; 31(2):54-76.
100. Ekelund ULF, Sjöström M, Yngve A, Poortvliet E, Nilsson A, Froberg K, Wedderkopp N, Westerterp K. Physical activity assessed by activ-ity monitor and doubly labeled water in children. M ed Sci Sports Exerc 2001; 33(2):275-281.

101. Janz KF, Levy SM, Burns TL, Torner JC, Willing MC, Warren JJ. Fatness, physical activity, and television viewing in children during the adiposity rebound period: The lowa Bone Development Study. Prev M ed 2002; 35(6):563-571.

102. Pietrobelli A, Faith MS, Allison DB, Gallagher D, Chiumello G, Heymsfield SB. Body mass index as a measure of adiposity among children and adolescents: a validation study. J Pediatr 1998; 132(2):204210.

103. Lindsay RS, Hanson RL, Roumain J, Ravussin E, Knowler WC, Tataranni PA. Body mass index as a measure of adiposity in children and adolescents: relationship to adiposity by dual energy $x$-ray absorptiometry and to cardiovascular risk factors. J Clin Endocrinol M etab 2001; 86:4061-4067.

104. Gutin B, Litaker M, Islam S, Manos T, Smith C, Treiber F. Body-composition measurement in 911-y-old children by dual-energy $X$-ray absorptiometry, skinfold-thickness measurements, and bioimpedance analysis. Am J Clin Nutr 1996; 63(3):287-292.

105. Kettaneh A, Heude B, Lommez A, Borys JM, Ducimeticre $P$, Charles MA. Reliability of bioimpedance analysis compared with other adiposity measurements in children: The FLVS II Study. Diabetes M etab 2005; 31(6):534-541.

106. Lyman WD, Barone C, Castle V, Davies HD, Stanton B, Paneth N.Making the National Children's Study a real part-nership with academic Pediatrics. J Pediatr 2005; 147(5):563-564.

Received 21 June 2008

Accepted 11 September 2008 